\title{
Effect of oxygen states in horizontal subsurface flow constructed wetlands on the removal of organic matter, nutrients, some metals and octylphenol
}

\author{
An Truong Nguyen, Tam Minh Thi Le*, Viet Quoc Tran, Viet Ngoc Truong, Luan Thanh \\ Nguyen, Phi Hoang Tan Nguyen, Trang Huyen Thi Nguyen
}

\begin{abstract}
Constructed wetland is a low cost, effective technology and it is still in the state of improvement to enhance the treatment efficiency, especially in nutrient and trace elements treatment. This study investigated the effect of aerobic and anoxic conditions in Horizontal Subsurface Flow Constructed Wetland (HSFCW) on nutrient, organic, metal and Octylphenol - OP (Endocrine disrupting chemical) treatment. Two HSFCWs were constructed: HSFCW1 with three aerobic compartments; HSFCW2 with two aerobic compartments, one anoxic compartment. The two HSFCWs had the same design parameters (fiters, plants), except oxygen conditions. The results showed that aerobic and anoxic HSFCW may increase the efficiency of Nitrogen removal by $10 \%$, but decreased by $11 \%$ in the efficiency of OP treatment (one of the EDCs). The efficiency of treatment of pollutants, including $\mathrm{NH}_{4}{ }^{+}-\mathrm{N}, \mathrm{COD}, \mathrm{TP}, \mathrm{Mn}, \mathrm{Fe}, \mathrm{Al}$ and $\mathrm{Cu}$ between two HSFCWs were not significantly different; the average efficiency was $99 \%, 84 \%$, $97 \%, 96 \%, 96 \%, 72 \%$ and $73 \%$, respectively. Therefore, the anoxic compartment of HSFCW still provided the effective removal of organic matter,
\end{abstract}

Manuscript received September $29^{\text {th }}, 2017$; accepted $24^{\text {th }}$ December, 2017

This study was funded by CARE RESCIF under grant number Tc-TTC-2017-05.

An Truong Nguyen, Tam Minh Thi Le, Viet Quoc Tran, Trang Huyen Thi Nguyen are with the CARE, Ho Chi Minh City University of Technology, VNU-HCM, Vietnam (truongan.hcmut@gmail.com, minhtamnt2006@hcmut.edu.vn, ngthtrang@hcmut.edu.vn)

Viet Ngoc Truong, Luan Thanh Nguyen, Phi Hoang Tan Nguyen are with the Faculty of Environment and Natural Resources, Ho Chi Minh City University of Technology, VNUHCM, Vietnam (truongngocviet93@gmail.com) metals and octylphenol, but it also improved nitrogen removal efficiency by up to $92 \%$.

Index Terms-Horizontal Subsurface Flow Constructed Wetland, Oxygen, Phragmites australis, Nitrogen, Metals, Octylphenol.

\section{INTRODUCTION}

Tref nefficient wastewater treatment or directed discharge pollutants containing nutrient contaminants (nitrogen, phosphorus), organic (e.g. BOD, COD), hazardous (e.g. metals, PCB) and trace elements (Antibiotics, pesticides, endocrine disrupting chemicals - EDCs) can pollute the water environment. Over-discharge of nutrient contaminants leads to eutrophication, which is one of the global problems that negatively impact on water quality for domestic, industrial and agricultural usage [1]. In addition to eutrophication, the presence of trace metals, EDCs in water threatens to human health, especially endocrine system disorders [2]. Biological process or biofilm (MBR) is a widely used technology nowadays, but demanding high costs of operating and consuming large amounts of energy; This leads to a limited access of the remote rural areas to these technologies [3]. Therefore, there is a need for an alternative technology that ensures the ability to remove nutrient contamination, trace elements, as well as minimal energy demand and operating costs. One of friendly environment technology, Constructed Wetlands (CWs) is a technology that satisfies the costs of operating and removal efficiency [4]. CWs are built to simulate the processes of treating pollutants in the nature, 
with the appropriate human modification for efficient wastewater treatment through the physical and chemical, biological processes thanks to the composition of plant, filter materials (sand, gravel, rock) and microorganisms [5], they can remove $51 \% \mathrm{TN}, 54 \% \mathrm{TP}, 63 \% \mathrm{COD}$ and also hazardous substances such as metals, EDCs [6]. The heavy metals are removed or retained through several mechanisms including: uptake of vegetations, adsorption on sediment or deposition in by both aerobic and anoxic/anaerobic processes [7]. These mechanisms work also on EDCs removal by constructed wetlands, because the main removal pathways of the target EDCs is their biodegradation [8].

Although plants and microorganisms are capable of treating nutrient contaminants like nitrogen, in order to remove completely nitrogen (i.e. Nitrogen is absorbed by microorganisms, plants or turn back gas N2), it is necessary to ensure both nitrification and denitrification occurring in CWs [9]. The low dissolved oxygen concentration (DO) in CWs leads to an incomplete nitrification and the nitrogen is not effectively treated [9]. There is some method to raise DO in CWs, such as applying Horizontal Subsurface Flow Constructed Wetland (HSFCW) and using an aeration pump to ensure aerobic conditions in $\mathrm{HSFCW}$, it can increase the TN removal by $25 \%$ to $51 \%$ compared to no-aeration CWs [9].

There have been many studies to improve the efficiency of nutrient contamination in CWs by maintaining aerobic condition for nitrification. However there are very few studies about the denifitrication in HSFCW, even the denitrification is extremely necessary for TN entirely removal [10]. This study evaluated the effect of the combined aerobic and anoxic HSFCW on nutrient, organic, metals and octylphenol - OP (Endocrine disrupting chemical) treatment efficiency.

\section{MATERIALS AND METHODS}

\subsection{System configuration}

Two HSFCW models were located at Bach Khoa University, exposed to natural air with a size of $2.4 \mathrm{~m} \times 0.9 \mathrm{~m} \times 0.8 \mathrm{~m}(\mathrm{~L} \times \mathrm{W} \times \mathrm{H})$, each HSFCW was divided into 3 compartments, each compartment $2.4 \mathrm{~m} \times 0.3 \mathrm{~m} \times 0.8 \mathrm{~m}$. The threecompartment HSFCW1 was aeration; HSFCW2 only having the first and third aeration compartments and the second compartment was prevented to the oxygen (Fig 1). Both HSFCW systems used Phragmites australis (except for second compartment of HSFCW 2), filter materials were $50 \mathrm{~cm}$ thick, including $5 \mathrm{~cm}$ gravel $(\mathrm{D}=30$ $50 \mathrm{~mm}), 20 \mathrm{~cm}$ small gravel $(\mathrm{D}=5-8 \mathrm{~mm}), 15 \mathrm{~cm}$ quartz sand $(\mathrm{D}=1-2 \mathrm{~mm})$ and $10 \mathrm{~cm}$ rock $(\mathrm{D}=$ $12-15 \mathrm{~mm})$ in the order from the bottom to the HSFCW surface.

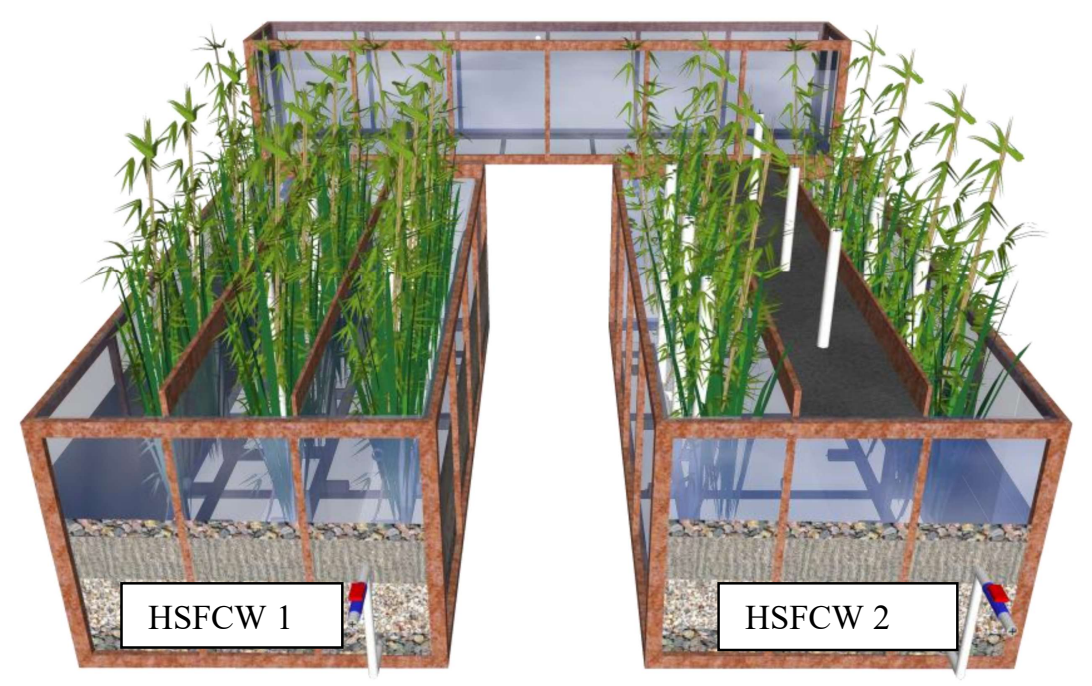

Fig 1. Schematic of the pilot-scale HSFCW, HSFCW1: aerobic HSFCW, HSFCW2: combined aerobic and anoxic HSFCW

\subsection{Operation conditions and sampling}

The influent wastewater used in this study was diluted landfill leachate which was obtained from a 
closed landfill in Ho Chi Minh City (Vietnam). The characteristics of the influent are shown in Table 1. In the first 60 days, the systems were fed with tap water and diluted wastewater for bed layer stabilization and plant adaptation. Then they were operated officially in 30 days with 6 days of hydraulic retention time (HRT) and 60L/day of hydraulic loading rate (HRT), it means the wastewater was kept two days in each compartment of HSFCW.

Samples were taken every 2 days, at four sampling points: influent, end of the first

TABLE 1

INFLUENT CHARACTERISTICS (MEAN \pm STANDARD DEVIATION, N=4) IN HSFCW

\begin{tabular}{|c|c|c|c|c|c|c|}
\hline \multicolumn{2}{|c|}{ Nutrient (mg/L) } & \multicolumn{2}{|c|}{ Metals $(\mu \mathrm{g} / \mathrm{L})$} & \multicolumn{2}{|c|}{ EDCs (ng/L) } & $\mathrm{DO}(\mathrm{mg} / \mathrm{L})$ \\
\hline COD & $381.11 \pm 40.20$ & $\mathrm{Al}$ & $66.18 \pm 6.26$ & $\mathrm{OP}$ & $412.59 \pm 70.98$ & $0.43 \pm 0.15$ \\
\hline $\mathrm{TP}$ & $32.96 \pm 3.47$ & $\mathrm{Fe}$ & $1337.93 \pm 172.88$ & - & - & - \\
\hline $\mathrm{NH}_{4}{ }^{+}-\mathrm{N}$ & $127.87 \pm 6.49$ & $\mathrm{Mn}$ & $91.15 \pm 9.82$ & - & - & - \\
\hline $\mathrm{NO}_{3}{ }^{-}-\mathrm{N}$ & $1.96 \pm 0.21$ & $\mathrm{Cu}$ & $50.78 \pm 5.20$ & - & - & - \\
\hline $\mathrm{NO}_{2}{ }^{-}-\mathrm{N}$ & $3.94 \pm 3.51$ & - & - & - & - & - \\
\hline
\end{tabular}

2.3. Analytical methods and statistical analyses

Chemical Oxygen Demand (COD), Ammonium $\left(\mathrm{NH}_{4}{ }^{-}-\mathrm{N}\right)$, Nitrate $\left(\mathrm{NO}_{3}^{-}-\mathrm{N}\right)$, Nitrite $\left(\mathrm{NO}_{2}^{-}-\mathrm{N}\right)$, Total Phosphorus (TP) and Metals (Al, Fe, Mn, $\mathrm{Cu}$ ) were analyzed according to Standard Methods [11]. Octylphenol (OP) in wastewater were determined after filtration and processed as previously described by Minh et al. (2016) [12]. Dissolved Oxygen (DO) were measured by Multi WTW 3210. compartment, end of the second compartment and end of the third compartment (output sample) of each HSFCW. Environmental parameters are checked at the sampling site. Samples were analyzed in the sampling day, or freezed at $-18^{\circ} \mathrm{C}$ for later analysis. During the 30 days operation, there were four operation times equal to four HRTs, each HRT lasted 6 days and. The values in Table 1 were the average values of 4 operation times $(\mathrm{N}=4)$.

\section{RESULTS AND DISCUSSION}

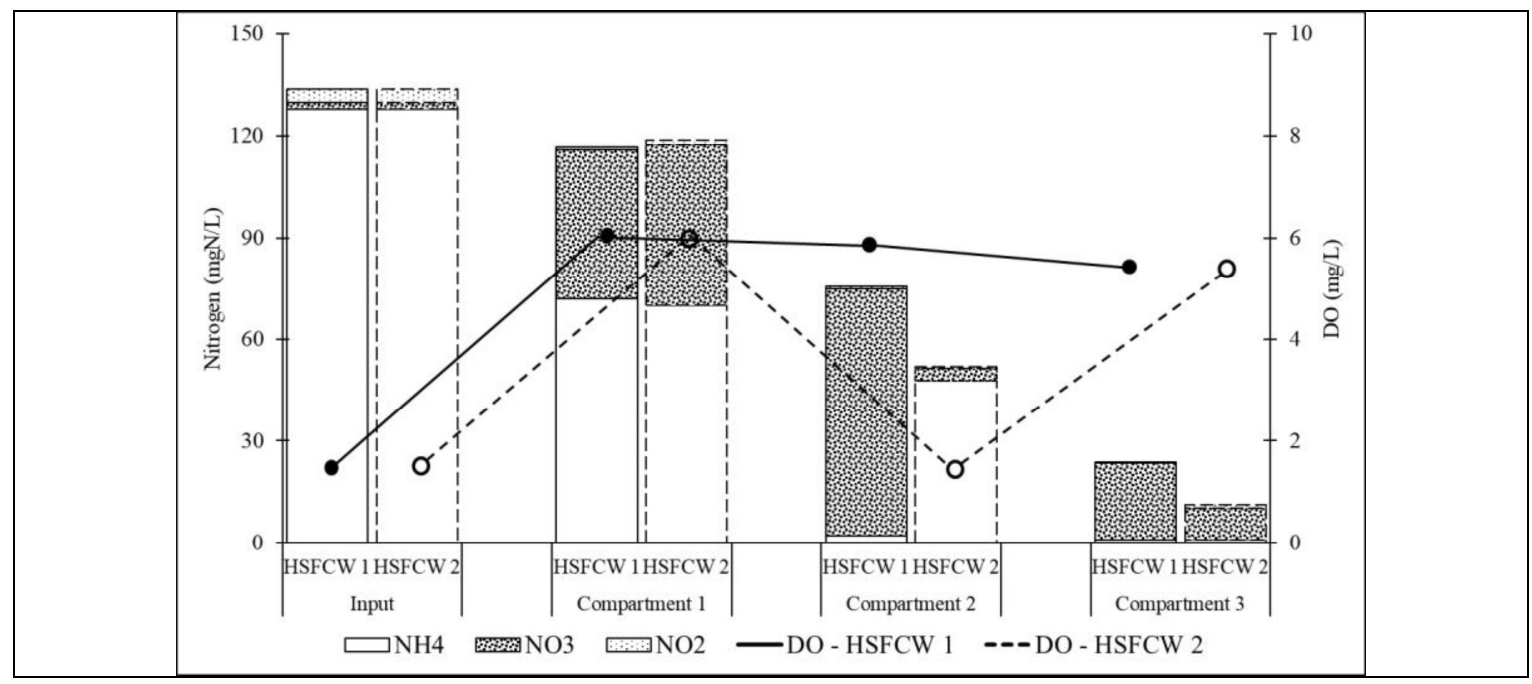

Fig 2. Comparison the changes of $\mathrm{NH}_{4}{ }^{+}-\mathrm{N}, \mathrm{NO}_{3}^{-}-\mathrm{N}, \mathrm{NO}_{2}^{-}-\mathrm{N}$ concentrations between $\mathrm{HSFCW} 1$ and HSFCW2 


\subsection{Effect effect of aerobic and anoxic conditions $H S F C W$ on on nitrogen removal efficiency}

The total nitrogen concentration (TN) including $\mathrm{NH}_{4}{ }^{+}-\mathrm{N}, \mathrm{NO}_{3}^{-}-\mathrm{N}$ and $\mathrm{NO}_{2}^{-}-\mathrm{N}$ of both HSFCWs gradually decreased following each compartment. There was a significant difference in the concentrations of $\mathrm{NH}_{4}{ }^{+}-\mathrm{N}$ or $\mathrm{NO}_{3}{ }^{-}-\mathrm{N}$ in the second compartment between two HSFCWs $(\mathrm{P}<0.01)$ which helped HSFCW2 (combined aerobic and anoxic CWs) get the $\mathrm{TN}$ removal ability better than HSFCW1 (aerobic CWs), as results $92 \%$ and $82 \%$ of TN treatment efficiency, respectively. However the t-test results showed that there was no difference in $\mathrm{NH}_{4}{ }^{+}-\mathrm{N}$ treatment efficiency between the aerobic and combined HSFCW (P > 0.05 ), their efficiency reached up to $99 \%$ of $\mathrm{NH}_{4}{ }^{+}-$ $\mathrm{N}$ removal. The main reason leading to $\mathrm{TN}$ removal differences in two HSFCWs was the ineffective treatment of $\mathrm{NO}_{3}^{-}-\mathrm{N}$ in the second compartment of HSFCW1.

The $\mathrm{NH}_{4}{ }^{+}-\mathrm{N}$ concentration of the two HSFCWs decreased by $44 \%$, equivalent to $55 \mathrm{mg} / \mathrm{L} / 2 \mathrm{~d}$ after going through the first compartment. The reduction of $\mathrm{NH}_{4}{ }^{+}-\mathrm{N}$ concentration was due to the absorption of reeds and microorganisms, and thanks to the nitrification process $(\mathrm{DO}>5 \mathrm{mg} / \mathrm{L})$ that converted ammonium into nitrate. Thus, $\mathrm{NO}_{3}{ }^{-}-$ $\mathrm{N}$ levels increased to $45 \pm 2 \mathrm{mg} / \mathrm{L} / 2 \mathrm{~d}$ after the first compartment of HSFCWs.

The difference in design between the two HSFCWs was the second compartment of the HSFCW2, this compartment was designed to prevent the oxygen contact, while the second compartment of the HSFCW1 was aerated as the first and third compartment. For the denitrification in CWs, the DO requirement should lower than 0.5 $\mathrm{mg} / \mathrm{L}$ [1], DO concentration in the second compartment of HSFCW2 was $0.5 \pm 0.1 \mathrm{mg} / \mathrm{L}$ still ensured the denitrification performance, this was illustrated in Fig 2, with the reduction of $\mathrm{NO}_{3}{ }^{-} \mathrm{N}$ in HSFCW2 was $45 \pm 8 \mathrm{mg} / \mathrm{L} / 2 \mathrm{~d}$. Meanwhile, the levels of $\mathrm{NO}_{3}{ }^{-} \mathrm{N}$ in the second compartment of HSFCW1 continued to increase by $29 \pm 5$ $\mathrm{mg} / \mathrm{L} / 2 \mathrm{~d}$. It can be explained by the nitrification in HSFCW1, because the DO in this compartment was still higher than $5 \mathrm{mg} / \mathrm{L}$, which was able to convert $\mathrm{NH}_{4}{ }^{+}-\mathrm{N}$ into $\mathrm{NO}_{3}{ }^{-}-\mathrm{N}$. Therefore, $\mathrm{NH}_{4}{ }^{+}-\mathrm{N}$ concentration was removed $99 \%$ even just at the second compartment of HSFCW1. On the other hand, based on Fig 2, it was found that TN in the second compartment of HSFCW1 decreased by about $40 \mathrm{mg} / \mathrm{L}$, this $\mathrm{TN}$ reduction was mainly the reduction of $\mathrm{NO}_{3}{ }^{-} \mathrm{N}$. The reduction of $\mathrm{NO}_{3}{ }^{-} \mathrm{N}$, in this case, was not due to the denitrification, but the
$\mathrm{NO}_{3}^{-}-\mathrm{N}$ absorption of the reed and microorganisms, which ranged from $20-40$ $\mathrm{mg} / \mathrm{L} / 2 \mathrm{~d}$. This means that plants and microorganisms in the HSFCW play an important role in the $\mathrm{NO}_{3}^{-}-\mathrm{N}$ treatment, which was easily seen in the third compartment (aerobic compartment) of both HSFCWs.

The third compartment of the two systems was aerobically designed, DO $>5 \mathrm{mg} / \mathrm{L}$, thus the nitrification happened in both HSFCW. Finally, $\mathrm{NH}_{4}{ }^{+}-\mathrm{N}$ in wastewater was eliminated $99 \%$ at this compartment, about $47 \pm 5 \mathrm{mg} / \mathrm{L} / 2 \mathrm{~d}$ in HSFCW2. However this nitrification was not significant for HSFCW1, since $\mathrm{NH}_{4}{ }^{+} \mathrm{N}$ was already removed $99 \%$ in the second compartment, but $\mathrm{NO}_{3}^{-}-\mathrm{N}$ was not significantly reduced at that compartment. It was also said that there still was a large amount of $\mathrm{NO}_{3}{ }^{-}-\mathrm{N}$ in HSFCW1 while its concentration in HSFCW2 was low. Therefore HSFCW2 gave a better $\mathrm{NO}_{3}^{-}-\mathrm{N}$ treatment efficiency than HSFCW1 as well as TN removal after all.

\subsection{COD and TP treatment}

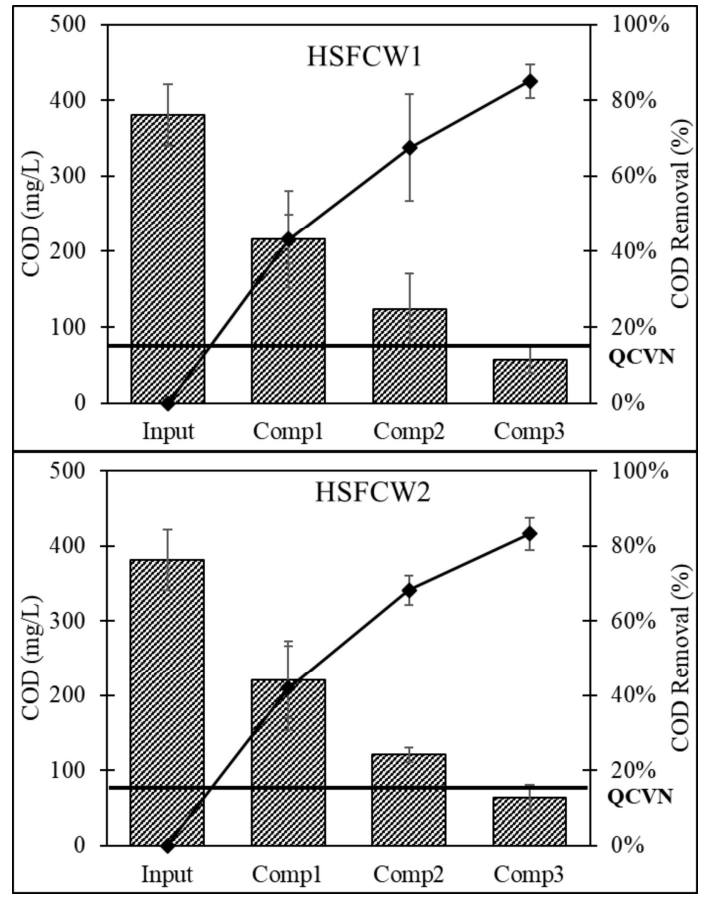

Fig 3. Changes of COD concentration and removal efficiency following each compartment (a) HSFCW1 and (b) HSFCW2

During the study period, the COD concentration decreased gradually through each compartment (Comp), the efficiency achieved over $80 \%$ (Fig 3) and there was no significant difference in removal efficiency between the two HSFCWs. Wastewater was transferred through the three compartments of the HSFCW with 6 days of HRT, equivalent to 2 
days per compartment. In 6 days of HRT, the treatment effect was significantly correlated with HRT $\left(\mathrm{R}^{2}>0.9\right.$, Fig 4), the effective treatment increased by $30-40 \%$ compared to the previous compartment, however the prolongation of HRT may result in a lack of correlation between HRT and the removal efficiency because of the treatment limitation of plants and microorganisms. Although the removal efficiency of COD could be improved under aerobic condition, in this study COD concentration in the anoxic condition (compartment 2 of HSFCW2) still provided a good treatment efficiency and there was no difference to the aerobic compartment of HSFCW1 $(\mathrm{P}>0.05)$. This result is quite similar to the research of $\mathrm{Li}$ et al. (2014) [9] which was stated that if the first and the last compartment of HSFCW were the aerobic conditions, the COD treatment efficiency would be ensured. In this study, all the first and third compartment of both HSFCWs were kept for DO $>5 \mathrm{mg} / \mathrm{L}$, so the COD efficiency of the two systems was quite similar. The efficiency of COD removal of HSFCW1 and HSFCW2 was $85 \%$ and $83 \%$, respectively, and the outlet concentrations were $57 \pm 17 \mathrm{mg} / \mathrm{L}$ and $64 \pm 17 \mathrm{mg} / \mathrm{L}$, they all met the National Technical Regulation on Industrial Wastewater (QCVN 40:2011/BTNMT) (Fig 4).

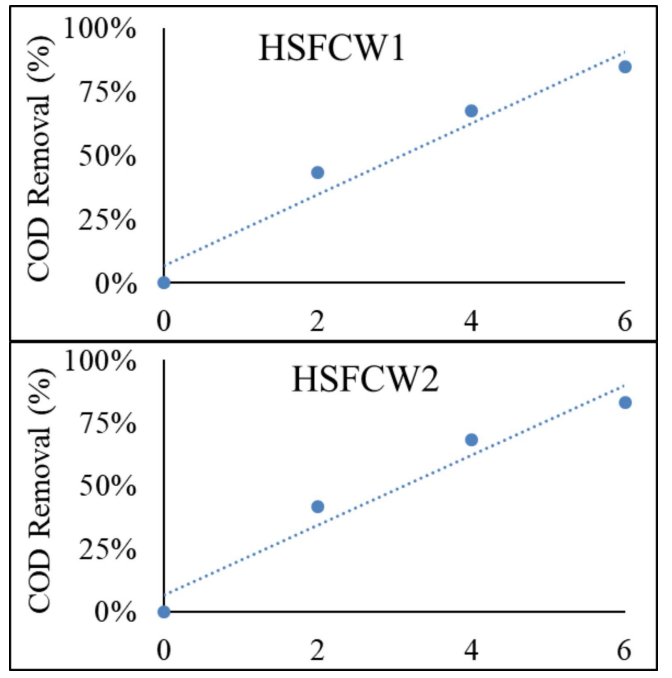

Fig 4. The correlation between COD removal and HRT (day)

The TP removal ability of the HSFCWs also has the same trend with COD for both HSFCW1 and HSFCW2. The efficiency of TP removal of HSFCW1 and HSFCW2 was 98\% removal and $96 \%$ respectively (Fig 5). In addition, in 6 days of HRT, TP removal efficiency has a high correlation with HRT $\left(\mathrm{R}^{2}>0.8\right.$, Fig 6$)$, it is also consistent with COD removal efficiency. At the end of the six days of HRT, the outlet concentration of the HSFCW1 and HSFCW2 the were $0.8 \pm 0.1 \mathrm{mg} / \mathrm{L}$ and $1.4 \pm 0.4 \mathrm{mg} / \mathrm{L}$, they all met QCVN 40:2011/BTNMT. Moreover, based on Fig 5 found in the second compartment of two HSFCWs, the TP removal efficiency reached to $90 \%$. It was also said that the usage of the anoxic or aerobic condition in the second compartment of HSFCW did not cause a significant effect to the TP removal efficiency $(\mathrm{P}>0.05)$.

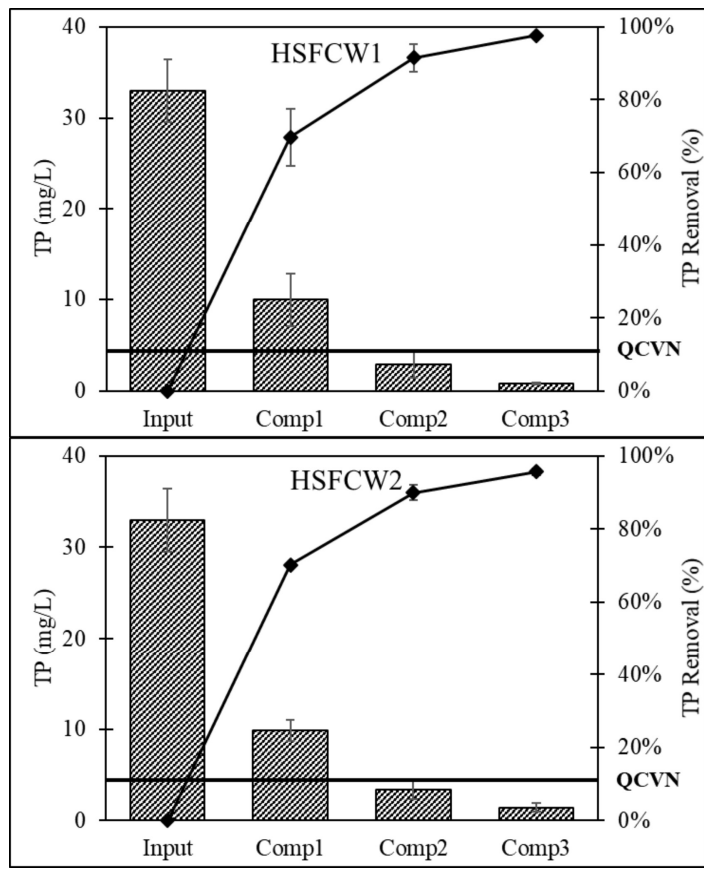

Fig 5. Changes of TP concentration and removal efficiency following each compartment (a) HSFCW1 and (b) HSFCW2

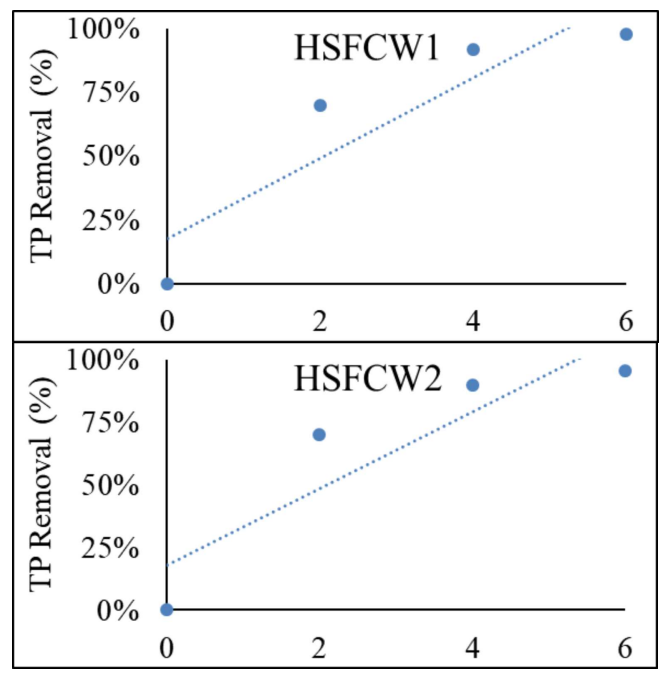

Fig 6. The correlation between TP removal and HRT (day) 

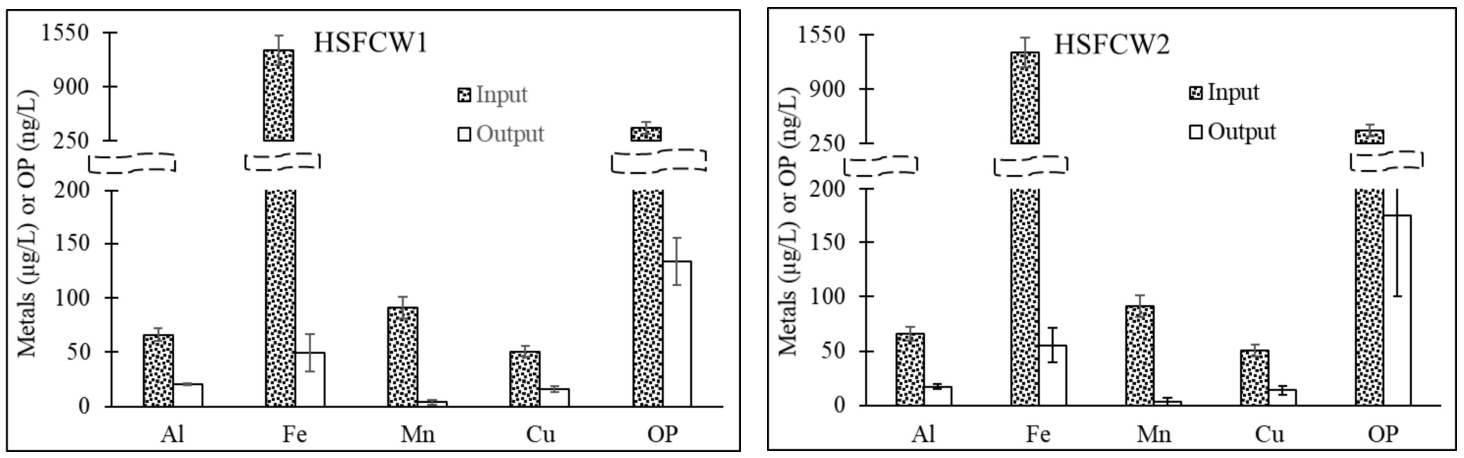

Fig 7. Input and output concentrations of Metals and EDCs in HSFCW1 and HSFCW2

\subsection{Metals and EDCs treatment}

The removal efficiency of metals ranged from $68 \%$ to $97 \%$ in both HSFCWs, especially Fe and Mn could be treated up to $90 \%$ (Fig 7), there was no difference in the efficiency of metal treatment between the aerobic HSFCW and the combined aerobic/anoxic HSFCW $(\mathrm{P}>0.05)$ in the metal removal. These results are also consistent with the review of Vymazal et al. (2016) on the heavy metals removal by HSFCW [7].

However, for the OP parameter (one of the EDCs) showed a slight difference, the HSFCW1 performed better than the HSFCW2, the efficiencies were $68 \%$ and $57 \%$ respectively. This difference can be attributed to the second compartment of the HSFCW2 which was lacked oxygen and vegetation. Although in the anoxic conditions, some of the EDCs could be removed better than aerobic HSFCW such as NPEO [8], OP in this study was not, the HSFCW1 with all three aerobic compartments and planted for better efficiency than the HSFCW2 that contained only two aerobic compartments.

\section{CONCLUSIONS}

The combination of aerobic and anoxic HSFCW has enabled both nitrification and denitrification processes, which helped the HSFCW2 removed nitrogen up to $92 \%$. In addition, the anoxic position in mid-HSFCW did not reduce the removal efficiency of other pollutants. Therefore, there were no significant differences in effective treatment of ammonium, COD, Metals, except OP. The removal efficiency for $\mathrm{NH}_{4}{ }^{+}-\mathrm{N}, \mathrm{COD}, \mathrm{TP}$, $\mathrm{Mn}, \mathrm{Fe}, \mathrm{Al}$ and $\mathrm{Cu}$ respective were 99\%, 84\%, $97 \%, 96 \%, 96 \%, 72 \%$ and $73 \%$. The removal efficiency of OP was $68 \%$ and $57 \%$ for HSFCW1 and HSFCW2, respectively.

\section{ACKNOWLEDGMENT}

Thanks, are given to members of FENR-CARE for laboratory work.

\section{REFERENCES}

[1] R. H. Kadlec and S. Wallace, Treatment Wetlands, Second Edition. CRC Press, 2008.

[2] I. Iavicoli et al., "The effects of metals as endocrine disruptors," Journal of Toxicology and Environmental Health, Part B, vol. 12, no. 3, pp. 206-223, 2009.

[3] A. Stare et al., "Comparison of control strategies for nitrogen removal in an activated sludge process in terms of operating costs: a simulation study," Water research, vol. 41, no. 9, pp. 2004-2014, 2007

[4] C. Ávila et al., "Emerging organic contaminants in vertical subsurface flow constructed wetlands: influence of media size, loading frequency and use of active aeration," Science of the Total Environment, vol. 494, pp. 211-217, 2014

[5] C. Ávila Martín et al., "Pharmaceuticals and personal care products (PPCPs) in the environment and their removal from wastewater through constructed wetlands," Comprehensive Analytical Chemistry, vol. 67, pp. 195244, 2015.

[6] J. Vymazal, "The use constructed wetlands with horizontal sub-surface flow for various types of wastewater," Ecological engineering, vol. 35, no. 1, pp. 117, 2009.

[7] J. Vymazal and T. Březinová, "Accumulation of heavy metals in aboveground biomass of Phragmites australis in horizontal flow constructed wetlands for wastewater treatment: A review," Chemical Engineering Journal, vol. 290, pp. 232-242, 2016.

[8] V. A. Papaevangelou et al., "Removal of Endocrine Disrupting Chemicals in HSF and VF pilot-scale constructed wetlands," Chemical Engineering Journal, vol. 294, pp. 146-156, 2016.

[9] $\mathrm{F}$. Li et al., "Three-stage horizontal subsurface flow constructed wetlands for organics and nitrogen removal: effect of aeration," Ecological engineering, vol. 68, pp. 90-96, 2014.

[10] F. Li et al., "Enhanced nitrogen removal in constructed wetlands: effects of dissolved oxygen and step-feeding," Bioresource technology, vol. 169, pp. 395-402, 2014.

[11] APHA., AWWA., and WEF., Standard Methods for the Examination of Water and Wastewater. American Public Health Association, 2012.

[12] T. L. T. Minh et al., "Presence of e-EDCs in surface water and effluents of pollution sources in Sai Gon and Dong Nai river basin," Sustainable Environment Research, 2016. 
An Truong Nguyen is a research assitant at CARE, HCMUT, Vietnam. He received the engineering degree in Environmental Engineering at HCMUT in 2016 and now he is a Master student at Grenoble INP, France.

Tam Minh Thi Le, she received the the B.S. degree in Environmental Engineering at HCMUT in 2009 and the M.S. degree in Environmental Engineering from Institute for Environment and Resources, Ho Chi Minh city, Vietnam, in 2011. She is currently pursuing the Ph.D. degree in Environmental Engineering at HCMUT, Vietnam.

Viet Quoc Tran, he is a technician at Care Rescif Center. He has been a master student in Environmental engineering at HCMUT and participated CARE's reseach project since 2015 .
Viet Ngoc Truong received engineering degree in Environmental Engineering at HCMUT in 2016. He has been a master student in Environmental engineering at HCMUT and participated CARE's reseach project since 2016.

Luan Thanh Nguyen, he is a student at HCMUT, studying about Enviromental Management $\mathrm{He}$ has participated CARE's reseach project since 2016.

Phi Hoang Tan Nguyen is a student at faculty of environment and natural resources at Bach Khoa University, studying Environmental Engineering. He has participated CARE's reseach project since he was third-year student.

Trang Huyen Thi Nguyen, she has been the vice Director of Centre Asiatique de Recherche sur l'Eau (CARE), Hochiminh city University of Technology (Vietnam) since 2013. Previously, she received her M.Sc. in 2008 and her doctoral degree in 2013 in France. 


\title{
Tác động của điều kiện oxi đến hiệu quả xử lý chất ô nhiễm dinh dưỡng và một số kim loại nặng và Octylphenol
}

\author{
Nguyễn Trường An, Lê Thị Minh Tâm, Trần Quốc Việt, Trương Ngọc Việt, \\ Nguyễn Thành Luân, Nguyễn Tấn Hoàng Phi, Nguyễn Thị Huyền Trang \\ Trường Đại học Bách khoa, ĐHQG-HCM \\ Tác giả liên hệ: $\underline{\text { minhtamnt2006@hcmut.edu.vn }}$
}

Ngày nhận bản thảo: 29-9-2017, ngày chấp nhận đăng: 24-12-2017

\begin{abstract}
Tóm tắt—Đất ngập nước kiến tạo là một công nghệ thân thiện với môi trường, có chi phí vận hành thấp nhưng vẫn đảm bảo hiệu quả xử lý, tuy nhiên cần có một số cải thiện về hiệu quả xử lý, đặc biệt chất dinh dưỡng và các chất vi lượng. Nghiên cứu này đánh giá tác động của điều kiện hiếu khí và thiếu khí trong hệ thống đất ngập nước kiến tạo dòng chảy ngang (HSFCW) tác động lên hiệu quả xử lý chất dinh dưỡng, hữu cơ, kim loại và octylphenol - OP (chất gây rối loạn nội tiết). Hai mô hình HSFCW được xây dựng với thông số thiết kế giống nhau, mổi hệ thống có ba ngăn, HSFCW1 có ba ngăn hiếu khí, HSFCW2 có hai ngăn hiếu khí và một ngăn thiếu khí, cả ha hệ thống đều sử dụng vật liệu lọc là cát, sỏi và thực vật (Phragmites australis) giống nhau. Kết quả cho thấy hệ thống kết họ̣p hiếu khí và thiếu khí giúp nâng hiệu quả xử lý Ni-tơ thêm $10 \%$, tuy nhiên lại giảm $11 \%$ hiệu quả xử lý $\mathrm{OP}$ (một trong các EDCs). Hiệu quả xử lý các chất ô nhiễm gồm $\mathrm{NH}_{4}{ }^{+}-\mathrm{N}$, COD, $\mathrm{TP}, \mathrm{Mn}, \mathrm{Fe}, \mathrm{Al}$ và $\mathrm{Cu}$ giữa hai hệ thống không có sự khác biệt lớn, hiệu suất trung bình lần lượt là $99 \%, 84 \%, 97 \%$, $96 \%, 96 \%, 72 \%$ và $73 \%$. Việc kết hợp với điều kiện thiếu khí giúp HSFCW nâng cao hiệu quả loại bỏ Ni-to, giúp loại bỏ đến 92\%, ngoài ra ngăn thiếu khí của HSFCW vẫn đem lại hiệu quả loại bỏ tốt các chất hữu cơ, kim loại và octylphenol.
\end{abstract}

Tù khóa—Đất ngập nước kiến tạo dòng chảy ngang, Nồng độ oxi, Phragmites australis, Nitrogen, Kim loại, Octylphenol. 